\title{
IMPACT OF DOCUMENTARY REQUIREMENTS OF STATE SUBSIDY GRANTS ON MORAL HAZARD VAS GYÖRGY ${ }^{1}$
}

\begin{abstract}
Lowering moral hazard is possible by proper incentives, therefore we examine the elements of the documentary request of the contract and the application of the state aid process. We conclude that the aim using administrative constraints is rather detecting fraud than fighting moral hazard issues. If the documentary requirement would aim treating moral hazard, it would shrink the number of companies eligible for tendering. Due to the second effect of documentary requirements lowering moral hazard is only possible if adequate quality measurers can be defined in form of an incentive for the tendering process and are rigorously controlled in the standstill phase of the development projects.
\end{abstract}

\section{INTRODUCTION}

State aid programs for micro, small- and medium sized companies contribute making unit cost of production lower in order to stimulate economic growth. However, firms are not transferring back funds in exchange as they do for loan-repayment but generate social surplus by executing projects ${ }^{2}$ in line with the development policy. Following (Varian 2014) consumer and producer surplus combined equals social surplus theoretically. For further consideration practically profit of companies alone can be used as right indicator, for two reasons. Once, SME's increase local supply, meaning that firms can launch products and services due to the positive effect of state aid grants in certain areas where availability was maleficent, if it is profitable. Second, any price decrease for increase in consumer surplus can have positive impact on social surplus only if firms don't suffer from losing profitability.

In case of commercial bank financing moral hazard can be defined as a hidden action, where the bank is not aware of the expected effort level of the firm, effecting the probability of success of the project. Using a unified model (Holmstrom \& Tirole, 1997) analyzed the common situation where firms and banks are also equipped with a constrained amount of capital, therefore both require outside sources to fund development projects. Firms' savings are insufficient to fully back the planned investment, while banks struggle to ensure enough credit facilities required by companies. This is described as credit constraint, a non-equilibrium situation, where changing incentives will also not help reaching equilibrium. Increasing interest rates will not improve lending, because the market does not believe in, that enterprises would start profitable projects or even if they are in position to launch such developments the funds requested for it would be used for cross financing purposes. In order to deal with the efficiency of non-refundable subsidies we should enhance the

\footnotetext{
${ }^{1}$ Budapest Corvinus University, SME research center, research associate

${ }^{2}$ We refer to project or development project in a broad since meaning that any investment, restructuring or change in production, marketing, sales or general management is considered
}

DOI: $10.14267 /$ RETP2019.04.15 
original model with central government, which is responsible for it. Recently (Berlinger E. J., 2015) (Berlinger, Lovas, \& Juhász, 2016) considered moral hazard issues of subsidies.

Several elements of the documentary details have the similar effect as the collateral requirements of bank financing. If a firm is defaulting, the bank is entitled to use the collateral for repayment. In case of commercial bank financing it is expected that the firm is generating enough cash to pay the installments, however in case of state-aid grants the authorities demand positive change in social surplus instead of loan repayment. In case of state aid grants there is no repayment, but firms have to contribute to economic development policies by increasing social surplus.

State intervention is regarded in different ways in the economic literature. The role of the state in corporate lending (J. Tirole 2009) sees in bail-out, based on the original (Holmstrom-Tirole 1996) model, which is a framework for examining the commercial bank lending and following (Berlinger, et.al 2016) it is considered also for state aid grants.

Empirical research was linked to car-insurance industry, by statistically measuring the effect of introducing incentives, like the bonus reward systems, in which case (Dionne 2005) (Richaudeau 1999) proved a significant drop of moral hazard. The price reduction given for accident free driving has a positive effect, i.e. there is no need to control the behavior if it can be found an incentive forcing the players to co-operate. (Cardon és Hendel 2001) (Abbring, Chiappori és Pinquet 2003) analyzed on large data sets the positive effect of any change in submitted claims of newly introduced incentives. The empirical analysis of moral hazard in insurance policies might be relevant to state-aid grants, if there can be found relevant incentives which might handle the unwanted outcomes of subsidies, rather than controlling behavior of firms. The same outcome might be achieved in fighting against subsidized development project without real social surplus by introducing powerful incentives rather than intending to pose administrative control on firms' spending. There is obviously further research needed in this matter.

By examining policy details of the business development details after the 2008 crisis (Vives 2010) considers the utilization of state aid grants. It is highlighted that the financial intermediary system has dramatically changed as commercial banks have sold part of their portfolio and reorganized its internal policies in order to decrease moral hazard. State intervention was regarded as regulatory policy, as trade-off between stability and competition.

(A. N. Berger 2006) proposed a general framework for studying the SME's access to credits, as relevant question both in economic theory and highly important for development policy maker. (L. Kállay 2014) examines the spill over effect of state aid subsidies, in case of increase in employment vs. investment, and better profit generation vs. competitiveness by proposing to monitor certain elements of the development policy even if the grants availability is in excess. We conclude that there are several similarities in commercial bank financing and state-aid subsidies, and therefore a similar comprehensive framework would be helpful for understanding real effects, however there is no such available, due to two basic reasons: once, the form and structure of state intervention varies even across member states of the European Union, second, the vast variety of the available products and its combinations. (Berger-Udell 2006) contributes with a coherence in SME financing, by linking the role of the bank ecosystem with state intervention policies to demonstrate how firms can access to credit.

In the framework of commercial bank lending (A. N. Berger 2006) summarizes the elements of items to be considered: methodology of credit policy, the source of information for submission, structure of the credit contract and the relationship management. There is a mixture of information 
derived from financial statements and quality information received from other sources. The same breakdown would be helpful for investigating state aid policies; therefore, we examine the documentary requirements in order to utilize the similarity of commercial bank lending experience.

\section{FrAMEWORK OF THE TENDERING PROCESS AND THE CONTRACTING PHASE}

The European Commission has the authority to control state aid subsidies in the European Union, and the emphasis is more on formality rather than examining the real effect on social surplus. Since there are several segments receiving grants: innovation driven sectors, economically underdeveloped regions, start-ups, and more generally small and medium sized companies, the proper utilization of state funds is highly important from economic development policy's point of view. The most relevant international empirical study concerning this was (Banerjee 2004), by investigating the anonymized data of different commercial banks. He concluded that return on investment measures the effects of commercial bank financing in both developed and underdeveloped markets.

The European Union regulates the forms of state interventions and the types of subsidies. For achieving the positive effect, i.e. increase social surplus approx. one percent of GDP was used for state aid grants totaling to EUR 100 billion (EuropeanComission 2018). The types of state aid grants show high variety, therefore cannot be defined such as typical subsidy-product, however it is expected that whey will be used for assisting non-equilibrium market segments, e.g. the micro, small- and medium size enterprises, since SME's face credit constraint and are not able to raise as much credit as they could utilize.

The 7-year planning period of 2007-2013 made some new products available, such as subsidized loan, grants, guarantee programs and venture capital financing as well, however before the 2014-2020 period new financing methods became available. Independently from the EU the National Bank of Hungary targeted the SME's by making widely available discounted credits in the framework of the Increase Development by Loans ${ }^{3}$ (NHP) program.

The real expenses associated with state-aid grants are awarded in different ways by beneficiaries. First, the methodology to determine net present value of the different types of grants is not unique, and secondly the perception of temporarily distributed cash-in and outflows might also vary. Consider now the several possibilities that companies can choose from if financing needs are present:

1. Credit line with a commercial bank

2. Discounted loan program by a development bank

3. Venture Capital financing

4. Capital market financing

5. State aid subsidy

The firm has exact knowledge about the profitability of its projects, by at least knowing the possible highest income and profit from the project. There is however a chance that there will be no social surplus after completion, i.e. no increase in profitability or in revenues. This is the

\footnotetext{
${ }^{3}$ We refer here to the Növekedési Hitelprogram (NHP) of National Bank of Hungary
} 
moral hazard of the state aid financing. It widens the question even more, if we consider that only the free money received from the state makes the project feasible, and without this financing it from commercial banking sources would have not been possible.

It is therefore highly important to set the precised goal of the investigation, whether we examine the successful operation of the development policy, or the intermediary system, or the development projects themselves. Furthermore, we aim to analyze the intermediary system responsible for absorbing the state aid grants to SME's, if we consider that administrative measurers might have negligible effect on the success of the development projects. There is unfortunately no internationally accepted methodology to detect the effects on economic development policy details derived from the state aid subsidized companies.

The EU supports delivering direct, non-refundable state aid grants to the micro, small- and medium sized companies, throughout a transparent and competition neutral intermediary system. (L. Kállay 2014) concludes that the aim of the Hungarian Development policy is to increase the competitiveness of the SME sector, by addressing credit constraint issues. There are several types of state aid grants available for Hungarian companies: the non-refundable grants, aiming to increase employment, investments and innovation, the tax and social contribution type of benefits, guarantee programs, venture capital financing and discounted loan programs. The similarity of the different programs lies in the decrease of unit costs of production. Therefore, we conclude that the successive operation of the intermediary system can be derived from the increase in profitability of the companies, which we interpret as social surplus.

The grants are transferred to the SME's after a formal decision, completion of the contracting phase and finally after execution of the development project. Monitoring of the project boils down to, checking the fulfillment of the administrative requirements, intending to secure that the non-refundable grants will not be used for any case related to fraudulent behavior, rather to contribute the boost social surplus.

The communicated goal of the Operational Program of Economic Development ${ }^{4}$ being part of the New Hungarian Development Plan as master document approved by the European Committee is economic development, strengthening the knowledge-based economy, supporting underdeveloped region, promoting to discover new export markets, and finally supporting the permanent economic growth.

For achieving economic development goals there are certain specific objectives defined, called priorities:

(i) Research and development, innovation capacity and cooperation

(ii) Increasing complex capacity of corporates

(iii) Developing business infrastructure

(iv)Access of SME's to required financing sources

Certain technical details might influence the tendering process, such as set up and operation of the Monitoring, the Governing, and the Paying Authority. Their complex aim indeed is to find

\footnotetext{
${ }^{4}$ In Hungary as GOP (2007-2013) and GINOP (2014-2020)
} 
the balance of achieving development goals of Operational Programs and utilize the possible maximum funds available by uncovering fraudulent activity. This activity requires control and management on quantitative criteria, if powerful qualitative elements would be involved it could make the transparent process doubtful.

The state aid subsidy grants of the European Union differentiate across public and private companies, government institutes and other organizations. The combination of the requested goal, the source, i.e. which European development fund is effected, and the form of subsidy will define the finally available maximum of the operational programs. Considering the statistics of the European Union, however, we conclude that the share of micro, small- and medium size enterprises was less than ten percent of the regional development programs and remained below three percent considering the sum of all the domestic subsidies. The huge number of companies receiving fund would require modification in the tendering, contracting and monitoring phase, but the execution is done by the same government agency.

\begin{tabular}{|l|l|l|l|l|l|l|l|l|}
\cline { 2 - 9 } $\begin{array}{l}\text { Years / Goal of } \\
\text { Subsidies }\end{array}$ & $\mathbf{2 0 0 9}$ & $\mathbf{2 0 1 0}$ & $\mathbf{2 0 1 1}$ & $\mathbf{2 0 1 2}$ & $\mathbf{2 0 1 3}$ & $\mathbf{2 0 1 4}$ & $\mathbf{2 0 1 5}$ & $\mathbf{2 0 1 6}$ \\
\hline $\begin{array}{l}\text { Regional } \\
\text { development }\end{array}$ & 342,0 & 284,7 & 241,6 & 273,1 & 319,7 & 839,5 & 426,7 & 760,4 \\
\hline SME's directly & 29,2 & 13,8 & 16,0 & 6,7 & 10,5 & 139,6 & 120,6 & 29,7 \\
\hline $\begin{array}{l}\text { Total domestic } \\
\text { subsidies }\end{array}$ & $\mathbf{1 3 3 9 , 7}$ & $\mathbf{2 0 6 7 , 4}$ & $\mathbf{1 2 0 4 , 1}$ & $\mathbf{1 1 9 3 , 8}$ & $\mathbf{1 4 9 5 , 2}$ & $\mathbf{1 6 8 5 , 6}$ & $\mathbf{1 4 4 3 , 7}$ & $\mathbf{2 3 9 1 , 6}$ \\
\hline
\end{tabular}

Source: EUROSTAT, Values in EUR millions

SME's might receive European Union's co-financed state-aid grants, development bank loans or financial guarantees. Economic growth is generated by firms with and without subsidies. We should consider the effect of firms benefiting from the discretionary policy, in relation to firms, which are not. There is no clear theoretical methodology of measuring social surplus. We define social surplus based on (Varian 2014) as the sum of consumer and producer surplus. It is not possible to measure it for the tens of thousand companies; therefore, we concentrate on the future effect of investment decisions on social surplus. Economic growth might be expected from increase in profit level of the SME's; therefore, we examine the potential positive effects of receiving grants.

The investment as a consequence of state-aid grant became bigger, the project generated larger profit and contributed to increase in social surplus, with

1. larger own contribution and larger bank financing,

2. larger own contribution but smaller bank financing,

3. smaller own contribution but larger bank financing,

The investment as a consequence of state-aid grant became bigger, but the project generated smaller profit and contributed to a lesser increase in social surplus, with

4. larger own contribution and larger bank financing, 
5. larger own contribution but smaller bank financing,

6. smaller own contribution but larger bank financing,

The investment as a consequence of state-aid grant became smaller, but the project generated bigger profit and contributed to a higher increase in social surplus, with

7. smaller own contribution and smaller bank financing,

8. smaller own contribution

9. smaller bank financing

The investment as a consequence of state-aid grant became smaller, but the project generated smaller profit and contributed to a lesser increase in social surplus, with

10. smaller own contribution and smaller bank financing,

11. smaller own contribution

12. smaller bank financing

After listing all possible outcomes, we examine the effect of the individual cases on economic growth. In the first group we have selected the most desirable cases from economic development policy perspectives. Social surplus increases with larger project size, leading to higher investment. This would potentially increase employment, bank lending and generate larger profit by SME's. This is in line with the main goal of economic policy, as (BANAI 2017) pointed out.

\section{ThE GOVERNING ROLE OF DOCUMENTARY REQUIREMENTS}

We can talk about moral hazard in case of the 3 plus 3 elements belonging to the second and fourth group, whereby due to the state-aid a different project size was selected, with lesser profit generation, i.e. we conclude that the social surplus became also smaller. Moral hazard lies in the modified social surplus of the development project, compared to the original intent of the firm implementing it without state-aid subsidies. The firm indeed might have different projects effecting profitability, therefore it might be misleading to derive the success of the project from the company's overall performance.

Moral hazard of state-aid can be reformulated as firms are accepting subsidies by knowing that the new development project will not have the optimum size, it might be bigger or smaller, but the increase in net revenues or profit lags behind compared to the original project without any restriction of documentary requirements. Any restriction might alter the development project's success, therefore, to understand the planned hidden action of the firm regulators should understand what would have been the real project size without state-aid grant, or in other worlds, what is the firms understanding of optimum project size.

In the following we turn to the different elements of the state-aid tendering and final contracting documentation requirements. The grants can be defined in four different ways regarding backwards the effective date: (1) the year of the grant was transferred, or (2) all contracts have been mutually signed, or (3) the positive decision was communicated by the authorities, or (4) the tender documentation has been submitted. There might be several differences in the effec- 
tive calendar year of the grants, which makes more difficult statistically to capture the business development effect ${ }^{5}$. The grants are equipped with the following criteria:

- the calendar year of submitting tender documentation

- amount of subsidy / grants in tender documentation

- amount of subsidy / grants in final contract

- the calendar year of contract signed

- amount of subsidy / grants financially settled

- the calendar year of financial settlement

- size of the development project

- own contribution to the project

- partner's contributions to the project

- the form of subsidy

- the final goal to be achieved using state aid funds

Considering the sets of data to be submitted in the tendering process until the contracting phase we can understand all details the information basis, on which the development project is accepted, subsidized and monitored.

- Admission of the project

All quantitative project details are presented, including a long-term business plan and an impact analysis. All financing needs and sources such as commercial bank loans, other subsidy grants and different business partners' contributions. All documents required for submission have to in original format and have to be signed by the company. The tendering process starts with introducing the company and the planned development project. Concentrating on the impact of the planned project the firm has to prove its capability of proper execution and financial support. Beside that a long-term business modelling has to be submitted as well, consisting all relevant information in a pre-defined format.

- Proof of legitimacy and completeness check

Any project has to undergo a legitimacy check, which is by definition a quantitative approach. If any shortage prevails then there is one single opportunity to deliver the missing documents, unless the submission for subsidy will be rejected.

- Content assessment, evaluation and approval

Evaluation is performed by independent personnel on anonym documentation, which should ensure a neutral approach to all tenders. Formal elements are checked for validity and by considering long term business plan this time the viability and reasonability is analyzed for approval.

- Signing the contract of subsidy

After the decision for subsidy has been made the contracts will be signed by both parties, or so-

${ }^{5}$ Take the example: submitted in late 2014, decision made in 2015, contracted in early 2016, and financially settled only in 2017. This comprises 4 calendar years, making it highly difficult to assign the positive effect of business development to a specific year. 
metimes even by several parties involved. The contract contains all details regarding execution of the development projects and also all penalties associated with non-performance or partial fulfillment.

- Financial settlement after executing the project

State aid subsidy grants in Hungary for micro, small- and medium size enterprises are post financed after execution, if the projects' indicators are successfully and in detail presented and are complete and fully in line with the development policy requirements. This measure is merely a snapshot providing no further incentives for company to perform orderly in the standstill period.

- Monitoring phase

The standstill period of the projects the companies shall submit to inspections. The state aid subsidy grants shall be only repaid fully or partially if inspectors will ascertain any irregularity. Considering the eligible costs, the industry and regional restrictions it has to be shown the fitting of the project to certain economic development goals ${ }^{6}$, detailing start, financial settlement and end date, standstill obligation period and other limitations. All of these criteria are neutral from moral hazard point of view, except eligible expenses, but this is still a restriction and not an incentive to alter future actions. Social consultation and dialog might have more positive impact on development projects than the disqualification of certain form of expenses. Those are for example the rental expenses and the infrastructural investments of research, development and innovation, or licenses and know-how rights, or general management costs. The aim of monitoring remains simply to prevent any fraudulent activity.

\section{Conclusions}

The most relevant and binding document of the state aid subsidies is the contract. Substantive parts of the documentary requirements consisting both qualitative and quantitative information might have impact on moral hazard issues. As we concluded earlier that shortage of qualitative criteria limit the useable tools of control, and leave merely a formality check of quantitative data, which might help detect fraudulent behavior, but is insufficient to tackle moral hazard issues. Closely monitoring all the project could guarantee more success but considering the huge number of projects and consequently companies effected, it is not feasible. The next table shows number of projects in question. The 7-year planning period between 2007 and 2013, followed two more years of project admission, approval and financial settlement resulted in approx. forty thousand cases.

Table 2: Number of Development Project

\begin{tabular}{|l|r|r|r|r|r|r|r|r|r|r|}
\hline Calendar Year & 2007 & 2008 & 2009 & 2010 & 2011 & 2012 & 2013 & 2014 & 2015 & TOTAL \\
\hline $\begin{array}{l}\text { Projects approved } \\
\begin{array}{l}\text { Projects financially } \\
\text { settled }\end{array}\end{array}$ & 3293 & 3168 & 5687 & 5647 & 7323 & 11196 & 6885 & 574 & 183 & 43956 \\
\hline
\end{tabular}

Source: MNB, Ministry of Finance, own collection

\footnotetext{
${ }^{6}$ As an example, we quote the Digital Welfare program setting new standards for IT infrastructure related projects
} 
If it would be more securities required in advance it would decrease the number of companies eligible, which is actually against the basic logic of the state aid subsidies. It is intended to subsidies SME's in order to loosen credit constraint by making available cheap financing sources for those companies, which one would have not been able to apply for commercial bank loan. Bank collaterals are risk management tools and are not aimed to secure profitability of the company. It is designed to incentives the company management and owners not to lower their performance level during project execution and operation, and not to seek for private benefit.

During the approval phase a formal check of the election criteria is done to ensure that all the submitted documents are valid and suitable. The substantive parts concentrate on the economic rationality and the expected impact on social surplus, all of these are ex-ante commitments, which should be closely controlled later. During monitoring and ex-post evaluation, however, there is only possible to analyze the company's performance.

It is still a question what type of documentary requirements could be added, when the communicated goal of the operational programs for micro, small- and medium size enterprises is strengthening the market presence of those companies. It can be achieved through increase in turnover and profit level, which will contribute to increase in accumulated profits and finally share equity. First, it should be differentiated between successful closing the development project and more profitable operation of the company itself, since the project might generate positive revenue, whereas the entire company might perform better or worse. From economic development policy point of view the company's performance should be regarded, however during monitoring solely the project. There is need for a detailed business plan of the project alone, in which all company internal physical and financial contribution should be accounted on the basis of the project. This could allow the Monitoring Authority to have better oversight on the subsidized project, which would guarantee at the end of the day the more profitable company operation and the fulfilling of economic development goals.

We identified moral hazard as a hidden action of firms, by lowering effort level causing lesser probability of success, which is materialized in private benefit instead of increasing social surplus. It is straightforward that it is not possible influencing the behavior of companies in advance. There is a need for control the behavior of companies after they have received non-refundable state aid grants, however the documentary requirements con not be made responsible for doing this. We conclude furthermore that monitoring can be only made based on the requirements set in the original tender documentation and in the contract. As pointed out previously qualitative measurers could be most welcome, however the logic and structure of the documentation requires rather quantitative indicators, since the fulfillment is unambiguous. This could be similar to the insurance industry incentives, where there is a proven record of success, that offering future financial benefits could have better controlling impact than closely monitoring the daily behavior.

If the Monitoring Authority were able to monitor closely the development projects than it could encounter moral hazard issues, which could be done on the basis of the documentary requirements of the tendering and contracting process. On the long run it would result in decreasing number of companies accepting state aid subsidy grants, but in case of successful project execution it could be more positive impact on social surplus. If firms in the standstill period might expect an effective control process than they would concentrate on keeping the promise they made in the tendering phase and they would follow the goals of economic development policy and the operational program, respectively. This would however, raise the operating expenses of the intermediary system, which also has to be considered. 


\section{REFERENCES}

Rafael Repullo, Javier Suarez (2000) Entrepreneurial moral hazard and bank monitoring: A model of the credit channel, European Economic Review, Volume 44, Issue 10, 2000, Pages 1931-1950,

Abbring, Jaap H., Pierre-André Chiappori, és Jean Pinquet. 2003. "Moral hazard and dynamic insurance data.". Journal of the European Economic Association 1.4.

Arnold, Lutz G., és John G. Riley. 2009. "On the possibility of credit rationing in the stiglitz-weiss model.". The American Economic Review.

Banerjee, A., and E. Duflo. 2004. "Do firms Want to Borrow More." Testing Credit Constraints Using a Directed Lending Program. Massachusetts Institute of Technology. Proessed.

Beck, Thorsten, Asli Demirgüç-Kunt, és Vojislav Maksimovic. 2004. "Bank competition and access to finance: International evidence.". Journal of Money, Credit and Banking.

Beck, Thorsten. 2007. "Financing constraints of SMEs in developing countries: Evidence, determinants and solutions." . KDI 36th Anniversary International Conference.

Berger, A. N., \& Udell, G. F. 2006. „A more complete conceptual framework for SME finance. Journal of Banking \& Finance, 30(11), 2945-2966."

Berger, Allen N., és Gregory F. Udell. 1995. Relationship lending and lines of credit in small firm finance.". Journal of business .

Berger, Allen N., és Gregory F. Udell. 2002. "Small business credit availability and relationship lending: The importance of bank organisational structure.". The economic journal 112.477.

Berger, Allen N., et al. 2004. "Bank concentration and competition: An evolution in the making.". Journal of Money, Credit, and Banking 36.3.

Berlinger, E., A. Lovas, és P. Juhász. 2016. State subsidy and moral hazard in corporate financing. Central European Journal of Operations Reserach.

Berlinger, E., Juhász, P., \& Lovas, A. 2015. „Az állami támogatás hatása a projektfinanszírozásra erkölcsi kockázat és pozitív externáliák mellett. Közgazdasági Szemle, 62(2), 139-171."

Carbo-Valverde, Santiago, Francisco Rodriguez-Fernandez, és Gregory F. Udell. 2009. "Bank market power and SME financing constraints.". Review of Finance 13.2.

Cardon, James H., és Igal Hendel. 2001. "Asymmetric information in health insurance: evidence from the National Medical Expenditure Survey.". RAND Journal of Economics"

Diaz-Serrano, Luis, és Frank Sackey. 2015. "Is Rationing in the Microfinance Sector Determined by the Microfinance Type? Evidence from Ghana.".

Dionne, Georges, et al. 2005. "The role of memory in long-term contracting with moral hazard: Empirical evidence in automobile insurance." . Available at SSRN 764705.

EuropeanComission. dátum nélk. European commision. (n.d.). http://ec.europa.eu/competition/legislation/treaties/ec/art88_en.html.

Griffith-Jones, Stephany, Judith Tyson, és Pietro Calice. 2011. The European Investment Bank and SMEs: Key Lessons for Latin America and the Caribbean. ECLAC.

Holmstrom, B., és J. Tirole. 1997. Financial intermediation, loanable funds, and the real sector. The Quarterly Journal of economics - JSTOR.

Kállay, L. 2014. Állami támogatások és gazdasági teljesítmény| Támogatás-túladagolás a magyar gazdaságfejlesztésben? Közgazdasági Szemle - Közgazdasági Szemle Alapítvány. 
Repullo, Rafael, és Javier Suarez. 2013. "The procyclical effects of bank capital regulation.". Review of Financial Studies 26.2.

Richaudeau, Didier. 1999. "Automobile insurance contracts and risk of accident: An empirical test using French individual data.". The Geneva Papers on Risk and Insurance Theory 24.1.

Ross, Stephen A. 1973. "The economic theory of agency: The principal's problem.". The American Economic Review 63.2.

Shen, Yan, et al. 2009. "Bank size and small-and medium-sized enterprise (SME) lending: Evidence from China.". World Development 37.4.

Sheng, J. (2016). „The Real Effects of Government Intervention: Firm-Level Evidence from TARP."

Stiglitz, Joseph E., és Andrew Weiss. 1981. "Credit rationing in markets with imperfect information.". The American economic review 71.3.

Stiglitz, Joseph E., és Andrew Weiss. 1981. „"Credit rationing in markets with imperfect information."." (The American economic review 71.3) 393-410.

Tirole, Jean. 1988. The theory of industrial organization. MIT press.

Varian, Hal R. 2014. "Intermediate Microeconomics: A Modern Approach", WW Norton and Company

Vives, Xavier. 2010. "Competition and stability in banking.".

Ylhäinen, Ilkka. 2010. "Persistence of government funding in small business finance." . Discussion Papers 1232 . 